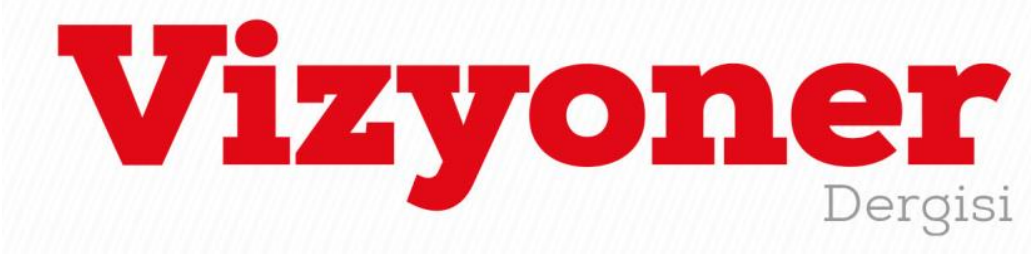

Süleyman Demirel Üniversitesi Vizyoner Dergisi, Yıl: 2021, Cilt: 12, Sayı: 30, 417-433.

Süleyman Demirel University Visionary Journal, Year: 2021, Volume: 12, No: 30, 417-433.

\title{
PROCESS ANALYSIS OF A PUBLIC POLICY IN TURKEY: MEDICAL TOURISM*
}

\section{TÜRKIYY'DE BİR KAMU POLITIIKASI SÜREÇ ANALIZİ: MEDÍKAL TURIZM}

\author{
Asst. Prof. Dr. Fatma KANTAŞ YILMAZ \\ Lecturer Haşim ÇAPAR ${ }^{2}$ \\ Lecturer Canan ŞEKER ${ }^{3}$
}

\begin{abstract}
Medical tourism field, which is a developing industry in terms of variety and popularity of medical interventions, generated in the formation of policy, implementation, understanding the efficiency and effectiveness would help to build Turkey's future projections. The purpose of the research is to analyze the policy of medical tourism in Turkey in the context of actors by using "Process Analysis Model". In the study which is designed with qualitative method, case study design and purposive sampling methods are used. The findings are analyzed by content analysis method under the headings of the model: agenda setting, formulation, legitimation, implementation and evaluation. The common opinion that the actors of medical tourism do not fully utlise the potential of medical tourism potential in Turkey, underlines the importance of enhancing the participation and collaboration of stakeholders in increasing the market share in Turkey.
\end{abstract}

Keywords: Politics, Turkey, Medical Tourism, Process Analysis.

JEL Classification Codes: I18.

$\ddot{O Z Z}$

Tıbbi müdahalelerin çeşitliliği ve popülerliği bakımından gelişmeye devam eden bir endüstri olan medikal turizm alanında üretilen politikaların oluşturulmasını, uygulanmasını, değerlendirilmesi, etkinliği ve etkililiğini anlamak; hiç şüphesiz ki Türkiye'nin gelecek projeksiyonlarının oluşturulmasına yardımcı olacaktır. Bu araştırmanın amacı, Türkiye'de medikal turizm politikalarını, aktörler bağlamında "Süreç Analiz Modeli" kullanılarak analiz etmektir. Bilimsel araştırma yöntemlerinden nitel yöntemle tasarlanan bu araştırmada, durum çalışması deseni ve amaçlı örnekleme yöntemleri kullanılmıştır. Çalışmadan elde edilen bulgular içerik analizi yöntemi ile Süreç Analiz Modelinde yer alan başlıklar altında ele alınmıştır. Bu başlıklar; gündeme geliş, formüle ediliş, kanunlaştırma, uygulama ve değerlendirmedir. Çalışma yapılırken medikal turizme taraf olan aktörlerin medikal turizm potansiyelimizi yeterince kullanamadığımız yönündeki ortak görüşü, Türkiye'nin medikal turizm alanındaki pazar payının arttırılmasında paydaşların katılım ve iş birliğinin öneminin altını çizmektedir.

Anahtar Kelimeler: Politika, Türkiye, Medikal Turizm, Süreç Analizi.

JEL Sınıflandırma Kodları: I18.

\footnotetext{
For this study the approval of ethical committee no 2020/10 dated 23.10.2020 was taken from the Ethical Committee, İstanbul Sabahattin Zaim University.

(D) Sağlık Bilimleri University, Faculty of Health Science, Health Management Program, fatmakantas.yilmaz@sbu.edu.tr

(D) İstanbul Sabahattin Zaim University, Faculty of Health Science, Health Management Program, hasim.capar@izu.edu.tr

3 (D) Nişantaşı University, Vocational School, Business Management Program, canan.arslan@nisantasi.edu.tr
}

Makale Geliş Tarihi / Received : : 01.10 .2020

Makale Kabul Tarihi / Accepted : : 01.04.2021 


\section{GENIŞLETILMIŞ ÖZET}

\section{Amaç ve Kapsam:}

Tıbbi müdahalelerin çeşitliliği ve popülerliği bakımından her geçen gün büyüyen ve gelişen bir endüstri olan medikal turizm; kardiyovasküler cerrahi, radyoterapi ve cyberknife gibi ileri tedavileri kapsadığı gibi infertilite, transplantasyon, estetik cerrahi gibi uygulamaları da içine alan kapsamlı bir alanı ihtiva etmektedir. Ülkeler için önemli bir gelir kaynağı olan medikal turizm alanında üretilen politikaların oluşturulması, uygulanması, etkinliği ve etkililiğini anlamak; küresel sağlık turizmi pazarında daha büyük bir paya sahip olmak isteyen Türkiye'nin gelecek projeksiyonları oluşturmasına yardımcı olacaktır. Bu çalışmada Türkiye'nin medikal turizm politikaları incelenirken, Süreç Analiz Modeli kullanılmıştır. Araştırmanın amacı Türkiye'de medikal turizm politikalarını, medikal turizme taraf olan aktörler bağlamında analiz etmektir.

\section{Yöntem:}

Türkiye'de medikal turizm alanında oluşturulmuş politikaları analiz etmek amacını güden bu çalışma, analiz metodu olarak “Süreç Analiz Modeli”ni (Laswell, 1956) kullanmıştır. Çalışmada medikal turizm politikaları analizi, dört temel aktör bağlamında gerçekleştirilmiştir: medikal turizm hizmeti veren hastaneler, karar verici konumundaki erkler, medikal turizm hizmetine aracılık eden acenteler ve medikal turizm alanında çalışma yapmış akademisyenler. Araştırmanın ana problemi Türkiye'nin medikal turizm politikalarına etki eden faktörlerin neler olduğudur. Araştırmanın deseni durum çalışması (örnek olay)'dır. Araştırmanın örneklemi; resmi sağlık otoritesi ( 1 adet), özel sektör birlikleri (3 adet), kamu hastanesi (1 adet), özel hastane ( 3 adet), ilgili alanda çalışma yapmış akademisyenler ( 3 adet), medikal turizm hizmeti sunan acenteler (4 adet)'dir. İlgili çalışma amaçlı örnekleme yöntemlerinden ikisi kullanılarak iki katmanlı bir örnekleme belirleme aşamasından geçmiştir: maksimum çeşitlilik örneklemesi ve benzeşik (homojen) örnekleme yöntemi. İçerik analizi kullanılarak analiz edilen çalışma elde edilen bulguları beş aşamada ele almıştır: Gündeme geliş, formüle ediliş, kanunlaştırma, uygulama ve değerlendirme. Haziran - Kasım 2019 tarihleri arasında İstanbul Türkiye'de gerçekleştirilen çalışma, veri toplama aracı olarak nitel araştırmalarda en sık kullanılan görüşme yöntemi kullanmıştır. Araştırmacılar tarafindan hazırlanan yarı yapılandırılmış görüşme formları, hastanelere, karar vericilere, akademisyenler ve acentelere yöneltilmiştir. Görüşmeciler tarafindan yüz yüze gerçekleştirilen görüşmeler, cihaz aracılığı ile ya da not alma şeklinde kayıt edilmiştir.

\section{Bulgular:}

Türkiye'de aktif bir şekilde 2000'li y1llardan sonra konuşulmaya başlanan medikal turizm kavramı, ilk olarak özel hastanelerin girişimi ile hayat bulmuştur. Aktörlerin büyük bir kısmı medikal turizmi bir iş fırsatı olarak görürken sadece politika üretici konumunda olanlar yabancı hastalardan gelen taleplerin medikal turizmi tetiklediğini düşünmektedir. Medikal turizmde y1llar içinde meydana gelen uygulamalar sonucunda medikal turizm politikalarının oluştuğu kanısı neredeyse tüm aktörlerin üzerinde uzlaştığı bir payda haline gelmiştir. Kendi çabaları ile pek çok farklı kanaldan reklam ve tanıtım faaliyeti gerçekleştiren özel sektör temsilcilerinin ortak kanaati, uluslararası tanıtım faaliyetleri için kamunun desteğinin önemli olduğudur. Uygulamada en çok ihtiyaç duydukları insan kaynağını; dil bilen, sağlığı bilen, yönetimi bilen insan kaynağı şeklinde tanımlayan taraflar, sağlık hizmetinin diğer tüm hizmetlerden pek çok açıdan ayrılan bir hizmet olmasının altını çizmektedir. Uluslararası kurallar ve malpraktisi medikal turizm uygulamalarının önünde bir engel olarak görmeyen hastanelerin büyük kısmı, ülkemizdeki yasal ve farklı sınırlandırmaların kendilerini engellediği kanaatindedir. Tüm katılımcılar, hastaların sağlık hizmetinin tamamlayıcı yan hizmeti olan otelcilik hizmetinden memnun olduklarını düşünmektedir. Bir sağlık tesisinin ulaşılabilirlik, hizmet kalitesi, doğru büyüme hedefleri, doğru tanıtım ve imaj şeklinde ifade ettiği medikal turizmde ülkemizin tercih edilme sebeplerine akademisyenler hep bir ağızdan "fiyat farkı (ucuz)" cevabını vermiştir. Sağlık tesisleri medikal turizmde akreditasyonun çok önemli olduğu noktasında hemfikir olup, üç sağlık tesisi de JCI Akreditasyon Belgesine sahiptir.

\section{Sonuç ve Tartışma:}

1990'lı yıllar itibari ile dünyada konuşulmaya başlanan medikal turizm fenomeni 2000'li yıllarda Türkiye'de gündeme gelmeye başlamıştır. Türkiye'de doğrudan medikal turizm üzerine yapılmış ilk çalışma, Gümüş ve Büyük (2008) tarafindan yapılmıştır (İçöz, 2009: 2259). Hastaları medikal turizmde bulunmaya zorlayan sebepler arasında, uzun bekleme süreleri, istenilen tıbbi tedavinin olmayışı, tıbbi bakım ücretlerinin yüksek olması, ülkedeki sağlık sistemine karşı olumsuz tutumlar gösterilmektedir (Çapar, 2019: 259; Khafizova, 2011: 10; Jotikasthira, 2010: 23). Buna karşın hastaları medikal turizme çeken sebepler; kaliteli ve göreceli ucuz bir sağlı bakım hizmeti alma isteği, erişimi kolay sağlık hizmeti, klasik turizm yapma firsatı ve güvenli bir sağlık hizmetini almak olarak ifade edilmektedir (Çapar, 2018: 106; Jotikasthira, 2010: 23; Awadzi ve Panda, 2005: 78; Marlowe ve Sullivan, 2007: 9). Türkiye'de medikal turizm kapsamında verilen hizmetler ve uygulamalar sonucunda medikal turizm politikalarının oluşmuş olması bu konuda ilk defa hizmet verilmeye başlandığında paydaşları yönlendirecek bir mevzuatın olmayışı ile açıklanmaktadır. Buzcu ve Birdir (2019) tarafından 206 özel hastane yöneticisi ile yapılan bir çalışmada medikal turizm konusunda hastane yöneticilerinin belirttiği sorun olarak sağlık mevzuatının dağınıklığı ve eksikliği gösterilmiştir. Türkiye'de medikal turizm hizmetini veren hastanelerin rakipleri ile mücadelede kullandıkları en güçlü silah, kaliteli hizmet ve düşük fiyat stratejisi olarak ifade edilmiştir. Konu ile ilgili yapılan bir çalışmada Türkiye, Hindistan ve Kosta Rika'dan sonra en çok yurt dışından hasta alan ülke olarak belirtilmiş ve bunun gerekçesi olarak da kaliteli düşük ücretli hizmet vermesine bağlanmıştır (Peters ve Sauer, 2011: 118). K1lınç (2017: 130) çalışmasında Türkiye'de medikal turizm hizmet kalitesinin iyi ve yeterli olduğu ancak uygulamada çalışanların iletişim problemi, aracı kurumların kapasitelerinin darlığg ve var olan potansiyelin tanıtılamaması gibi eksikliklerin var olduğuna dikkat çekmiştir. Yapılan bir diğer çalışmada Türkiye'de genel olarak iletişim ve koordinasyon ile ilgili problemler yaşandığı ifade edilmiştir (Aydın vd., 2011: 6). 


\section{INTRODUCTION}

Global growth in the flow of medical technology and capital financing as well as patients and healthcare professionals across national borders has resulted in new consumption and production models in healthcare services within the last decade. This new concept in health sector arising from the globalizing economy emerges as a phenomenon called "medical tourism" including selective actions of patients crossing borders in seeking medical treatment and health (Lunt et al., 2011; Ruggeri et al., 2018; Johnston, Crooks, Snyder and Kingsbury, 2010).

Health tourism is defined as trips planned outside the local environment of the individual in order to improve, heal and protect psychological and physical health. This definition includes the concept of "medical tourism" which is limited to improvement and development of individual's health through medical treatment (Lunt et al., 2011; Smith, Alvarez and Chanda, 2011). Medical tourism is the most important step of health tourism (Ayranc1, Ayaz, Yaşar and Yüksel, 2018). Although some authors have addressed medical tourism and health tourism as a united phenomenon, the concept of medical tourism, which is addressed in the context of international patients receiving services from healthcare institutions for treatment and rehabilitation, will be investigated in this study.

In this context, the purpose of the study, medical tourism policies in Turkey, in the context of actors "Process Analysis Model" is used to analyze. For this purpose, how it came to the agenda of Turkey medical tourism policy, how it is formulated after the agenda, the next implementation phase of the formulation and control processes will be examined. With the findings to be obtained as a result of this study, it is thought that evidence-based data will be provided to decision makers, service providers, agencies, academicians conducting scientific studies and other important stakeholders.

\section{POLICY PROCESS ANALYSIS}

Public policy, which defines the interactive relationship that states deem fit, plan to do, or a public institution has with its environment, is a process that consists of several stages (Çevik and Demirci, 2012).

The decisions taken by the governments that govern the states on education, health, national defense or foreign relations can affect the whole life of the citizens of that country. For this reason, it is necessary to act meticulously in the process of public policy formulation. Public policies that emerge as a result of a process are to be influenced by different actors as well as having a large area of influence. In addition, Policy includes the relationships between individuals, communities and organizations, and becomes more influential than decisions taken at the end of the process (Çevik and Demirci, 2012).

Although many different public policy definitions are made, public policy begins with the definition of a situation in the country as a problem; It continues with the determination of alternative solutions to the problem and determining the option that best serves the interests of the country (Birkland, 2019). According to Anderson (2014) public policy is used to describe the purposeful and planned activities of actors who come together to solve a problem.

In line with this definition, Anderson emphasizes that public policy should have certain features. When describing these features, Anderson's first thing to say is that public policy is not accidental; on the contrary, it serves a purpose. Underlining that the implementation process is an integral part of the policy-making process, Anderson underlined that policy demands are mostly from citizens. Finally, the binding nature of public policies, which take their power from laws, concerns all parties (Anderson, 2014).

It can be stated that the health policy making process generally starts with the determination of who and how the health service delivery in the country will be done. It is a process determined by the health policy to determine the sources from which the health services financing will be provided and which services will be provided. The willpower put forward by the governments to formulate health policies becomes very important considering the extent of the influence of health policies. The concept of health, which is one of the important factors determining the social welfare of the citizens of the country, is strictly dependent on the policies to be established on health. It can be stated that this situation makes the medical tourism policy, which is an important sector.

Public policy process analysis is a systematic study which is carried out to understand policy making process in any field, to detect accompanying stakeholders and their domains and to evaluate outputs of the process (Dye, 
2016). It is required to analyze policy pocesses in order to determine the features of policies made and to address their outcomes. Policy analysis also reveals the efficacy of the policies made. Many notable information can be obtained following analysis process that assesses all basic steps of policy process. While many different models can be used in policy analysis, this study was based on "Process Model". Process model, that is based on examining policy process by taking it apart with a gradual approach, is a comprehensive as well as practical method (Kapt1, 2011). Process approach acts with the idea that public policies are processes and address all parts making up the whole. Process model, which was described as seven stages by authors as Anderson (2014) and Dye (2016). The stages of this model, which was denoted by Sabatier (1991) in five stages, include agenda setting, formulation, legitimization, implementation and evaluation.

\section{METHODS}

Scientific studies including a systematic and consistent process should follow the truth. For this reason, research should be planned previously and undergo specific scientific steps. Therefore, the details of research process will be explained in this part of the study. Ethics approval was obtained from a foundation University Ethics Committee (IRB No: 23.10.2020/10).

\subsection{The Aim of the Study}

The aim of the study was to analyze policies made in the field of medical tourism in Turkey using "Process Analysis Model".

Walt and Gilson (1994) indicated that studies on health policy mostly focused on the content and neglected actors, context and processes. Health Policy Triangle created by these two authors (Walt and Gilson, 1994) sees actors, who are parties to the policy, as significant stakeholders of health policy making process. Therefore, the analysis of medical tourism policies in this study was carried out in the context of four main actors: providers of medical tourism service (hospitals), powers in decision-making positions, institutions mediating medical tourism services (agencies) and academicians working in the field of medical tourism.

\subsection{Study Design}

Since the analysis of medical tourism policies only indicates a particular situation or event, case study was preferred as the design of the study. Research process changes according to the event, situation or phenomenon that is the subject of qualitative research. Study design determining the approach of the study is therefore very important (Yıldırım and Şimşek, 2018). Case study is frequently used in qualitative research and refers to in-depth investigation of a particular situation. The aim in case studies is to reveal the outcomes of a particular case. It is impossible to generalize case studies because each case is unique. In addition, the outcomes of a case study can be guiding to understand similar cases.

\subsection{Sample of the Study}

Study sample was given in the Table 1 .

Table 1. Study Sample and Explanations

\begin{tabular}{|c|c|c|c|c|}
\hline Actors & Selection Criteria & Sample & $\begin{array}{l}\text { Institution/Number } \\
\text { of individuals }\end{array}$ & $\begin{array}{l}\text { Institutional } \\
\text { codes }\end{array}$ \\
\hline \multirow{2}{*}{ Decision makers } & $\begin{array}{l}\text { Private Sector } \\
\text { Associations }\end{array}$ & $\begin{array}{l}\text { Associations of Health } \\
\text { Organizations }\end{array}$ & 3 & \multirow[b]{2}{*}{$\begin{array}{l}\text { D1, D2, D3, } \\
\text { D4 }\end{array}$} \\
\hline & $\begin{array}{l}\text { Official Health } \\
\text { Authority }\end{array}$ & Official Health Authority & 1 & \\
\hline \multirow{2}{*}{ Providers } & Private Sector & Private Hospitals & 3 & \multirow{2}{*}{$\begin{array}{l}\mathrm{H} 1, \mathrm{H} 2, \mathrm{H} 3, \\
\mathrm{H} 4\end{array}$} \\
\hline & Public Hospital & City Hospitals & 1 & \\
\hline Researchers & Academicians & $\begin{array}{l}\text { Academicians working in the field } \\
\text { of health tourism }\end{array}$ & 3 & $\mathrm{~A} 1, \mathrm{~A} 2, \mathrm{~A} 3$ \\
\hline $\begin{array}{l}\text { Intermediary } \\
\text { institutions }\end{array}$ & Agencies & $\begin{array}{l}\text { Agencies providing health tourism } \\
\text { service }\end{array}$ & 4 & $\begin{array}{l}\text { AG1, AG2, } \\
\text { AG3, AG4 }\end{array}$ \\
\hline Total & & & 15 & \\
\hline
\end{tabular}


Relevant study went through a two-tier sampling phase by using two purpose sampling methods. Purpose sampling methods enabling in-depth investigation of the cases, which are believed to have a diverse and rich information, will help researchers to analyze medical tourism policies in Turkey in terms of discovering new information.

Maximum heterogeneity sampling was used in the first phase of sample determination process. The purpose of using maximum heterogeneity sampling is to make an analysis by including important actors who may become a part of the formation, implementation and evaluation process of medical tourism policies. The aim in maximum heterogeneity sampling is to create a relatively small sample and to reflect the opinions of the parties of the problems on certain issues (Yıldırım and Şimşek, 2018). Four main actors were determined by maximum heterogeneity sampling method due to the interactive relationship between medical tourism policies and the actors involved. The stakeholders included under these four basic categories were selected by homogenous sampling method. The goal of homogenous sampling method is to make a clear definition by creating small and similar samples. Subgroups carrying homogenous characteristics are similar based on the features such as carrying out medical tourism activities and high turnover.

\section{DATA ANALYSIS}

Content analysis was used in the study. The results of content analysis were addressed under the headings of five stages in the model including agenda setting, formulation, legitimization, implementation and evaluation. In each stage, how all actors affected public policy was explained. Main aim of content analysis is to make an in-depth analysis through conceptualization of data collected on common themes. The concepts retrieved at the end of this analysis are classified under a particular theme; and the associations between the themes are interpreted. Content analysis finds out the realities hidden in the data through this way, and makes cases and situations more clear (Yıldırım and Şimşek, 2018).

\subsection{Validity and Reliability}

The analyses performed were addressed under five main headings in the study. All analyses were carried out within the framework determined by the expertise fields of the researchers who made a contribution to this study; and individual analyses of each researcher were reshaped by the critics of the other researchers and continued until a consensus was provided. Researchers, who were concentrated on the subquestions included in each process of process analysis model, performed their analyses under common themes by conceptualizing the responses given by all actors. The answers given to the questions in the analysis part were systematically recorded on the excel tables created by the researchers. The method determined by the relevant study revealed a matrix: policy analysis process including 5 stages, 4 main actors and a total of 51 questions under 11 main headings. Therefore, researchers had the opportunity to analyse the results on a wide variety of axes. Analysis of each part was reviewed after a while and necessary revisions were made; and thus the reliability of the study was enhanced. Analyses were limited in the context of actors and questions under each section; comparative analyses of the sections were only evaluated in the results part.

\subsection{The Role of the Researchers}

This study was conducted in Istanbul/Turkey between June-November 2019. Interviewing method was used as data collection instrument; and a semi-structured interview form which was generated by the researchers was used. Four different semi-structured interview forms that were prepared for hospitals, decision makers, academicians and agencies were composed of 11 main topic headings and 51 subquestions. While semi-structured interview form was prepared, questions were grouped under five stages included in Process Analysis Model: agenda setting (questions 1,2,3,4,5), formulation (questions 6,7,8), legitimization (question 9), implementation (question 10) and evaluation (question 11). Ten interviews were performed as face-to-face. When required, sentence form and question order were changed in the interview form according to the course of the interview. Interview notes were recorded as voice recording or note taking in accordance with the consents taken from the participants. Interview notes of only one hospital were kept by hand; besides, data were collected from one decision maker and four agencies through email. During the interviews, answers were not directed to pre-prepared questions; only short explanations were made when required and where the participants could not understand. Interviews were made with a total of 15 relevant individuals through face-to-face or internet; and voice records were taken for 302 minutes and 59 seconds. These voice records were transcribed by the researchers and content analysis was carried out on a total of 30.849 words. 


\section{RESULTS}

This analysis of medical tourism policies in Turkey differs from its counterparts due to its outcomes. Information obtained from the data collected by the researchers of the relevant study were reported as follows.

\subsection{Identification of the Problem and Its Setting in the Agenda}

Agenda describes a community of problems, and it refers to all kinds of deficiencies that attract the attention of people living in the country. Creating a common will to put existing problems on the agenda and to solve them is an action initiating policy making process (Jann and Wegrich, 2007).

\subsubsection{Meeting The Reality of Medical Tourism, Having an Idea about Medical Tourism}

This study in which we performed the analysis of policies in the field of medical tourism with process model started by asking stakeholders when they first met the concept of medical tourism. Although all stakeholders told various times, consensus was that the concept of medical tourism began to be spoken actively after 2000s. When this situation is categorized among the stakeholders, it can be stated that decision makers met with medical tourism more previously than the other stakeholders [D1: 2002, D2: 2000, D3: 2010, D4:2004].

It is also possible to say that hospitals providing medical tourism service met this concept right after decision makers. Following the same question, hospitals mainly gave dates after 2010 for the question "When did you first start to provide medical tourism service in your hospital?" [H1: 2007-2009, H2: 2005-2006, H3:2005].

It was observed that international marketing and business development directors met medical tourism more previously and began to provide medical tourism service in their hospitals following an average of 6-7 years.

Academicians who are working in the field of medical tourism were the last to hear this concept among the stakeholders. Medical tourism, a new concept that was begun to be spoken in the world in the 1990s, has become the subject of many academic studies also in Turkey.

During in-depth interviews performed with the participants, the second question asked was "Which institution provided service in the field of medical tourism for the first time in Turkey?". Hospitals and decision makers that respond to this question concentrate on the names of two hospitals. The consensus on the names of these two private healthcare institutions show participants' thoughts indicating that private hospitals precede public hospitals in medical tourism.

The same question was directed to academician stakeholders as "Is the first study in the field of medical tourism belong to you?", and "no" was taken as the common response [A1, A2, A3]. However, one of the participants gave an answer as "I am the first academician who carried out a study on medical tourism emtrepreneurship" [A1].

\subsubsection{Perspective on Medical Tourism}

In our study, we asked all stakeholders about the reason of the emergence of medical tourism which has been put on agenda in our country since 2000s by public as well as private sector; and it was observed that participants emphasized two reasons. While one of these reasons was "demand", the other and the most frequently repeated was "business opportunity". Some of the participants indicated that they started to provide medical tourism service upon requests from foreign patients; and one of the participants who was a decision maker stated as follows:

"Medical tourism started with the increase in the population devoid of health insurance, health insurances not meeting all treatment services, insurance companies' seek for decreasing their costs, saving treatment costs, getting a more quality healthcare service, receiving a treatment service which can not be provided in their countries and the demands of foreign patients, who do not want to wait in line, for treatment; thus, travelling out of their countries." [D3].

One of the private healthcare institutions which regarded medical tourism service as a business opportunity tried to explain their perspective with the following sentence as "a health tourist spends 2500/3000 US dollars while a tourist spends 700/800 US dollars."[H1].

While private healthcare institutions, agencies mediating health tourism and even academicians working in the field of medical tourism see medical tourism as an "opportunity", it seems remarkable that decision makers who produce, implement and audit policies in the field of medical tourism responded this question as "the demand from 
foreign patients". Considering that the perspective on medical tourism may affect all actions and activities, the difference in the thoughts of the decision makers from all other stakeholders closely concerns all actors of medical tourism.

\subsubsection{The Relationship Between Medical Tourism Activities and Medical Tourism Policies}

The other question that will shed light on one of the indispensable elements of policy making process which is identification of problems and setting them in the agenda stage, was our question trying to understand the relationship between medical tourism applications and policies. Three common answers were given by the participants for the question as "are medical tourism applications effective on making policies in this field or do policies on medical tourism affect the applications?". Although our question was two-ended, emergence of a third answer shows that participants were focused on the questions.

The strongest option among the answers was the fact that medical tourism policies were made as a result of the applications of medical tourism during years [H3, A3, D1,D2, D3,D4,]. Another common answer confirming this emerges in the following questions. Everyone without exception stated that there was not any legislation to guide them when they were asked the question as "What kind of legislation/literature was present when you first began to provide medical tourism service/to carry out studies in the field of medical tourism?" [H1, H2, H3, H4, A1, A2, A3, D1, D2, D3].

All academician stakeholders agreed that national literature was limited but international literature was more rich when they first started to work in the field of medical tourism. One of the academicians responded the relevant question as follows: "I can not say that there is a wide range of studies in the national literature since it is very new. The literature was limited, but there are many studies in the foreign literature especially on medical tourism and medical tourism marketing" [A1]. In the light of answers given to the other questions, an additional question was asked only to decision making stakeholders. To our question asking whether we take the countries which are considered successful worldwide in policy making on medical tourism as an example or not, all decision makers responded as "no" [D1, D2, D3, D4]. Concerning the reason of this answer, one of the decision makers answered as “....my SWOT does not match their SWOT. Because the service they provide refers to a more relaxing treatment and a holiday displaced process. The service in Turkey is more surgery-oriented and the process requires high quality." [D1] whereas another decision maker gave an answer as “... there are many reports prepared by the Ministry of Treasury. In these reports, there are examples such as Thailand, Singapore and America but we can not find the one among these that is right and unique to us." [D2]. The decision making stakeholders, who are the most authorized in making medical tourism policies, have indicated that they follow the best examples but we can not apply them to ourselves.

\subsubsection{Medical Tourism Environment, Stakeholder Analysis}

In this study where we try to analyze how agenda is set in Turkey regarding the concept of medical tourism, another important question that we asked to stakeholders was whom they saw as stakeholders. It will be better to provide the most repeated ones among many answers given to this question by categorizing them.

Common stakeholders pointed out by the hospitals providing medical tourism service can be listed as follows: Ministry of Health, tourism agencies carrying out health tourism, associations and foundations making effort for the promotion of medical tourism including non-governmental organizations (NGOs) [H1, H2, H3]. The presence of the stakeholders included in our study within this list contributes the validity and reliability of our study.

When we asked academicians about whom they saw as stakeholders during their studies, we encountered universities, Ministry of Health and Ministry of Culture and Tourism [A1, A2, A3]. Decision makers responded to the same question with similar answers as well as airline transportation companies, International Health Services Inc. (USHAS), Health Tourism Coordination Council (SATURK), The Turkish Association of Private Hospitals and Health Institutions (OHSAD) and Turkish Association of Travel Agencies (TURSAB) [D1, D2, D3, D4]. Identification of the stakeholders was highly important to determine what affects medical tourism and what directs medical tourism policies. However, the most important fact was how identified stakeholders influenced medical tourism. During in-depth interview that we performed to understand this, we asked a new question to the participants to measure what kind of responses they received from the institutions and organizations which they considered as stakeholders. 
Their answers were concentrated on the keywords including response, collaboration, support and neutral. The number of the participants who declared that they received collaboration and support from their stakeholders [H2, A1, A3, D1, AG1, AG3] was found to be equal to the number of participants who saw a response or neutral behaviors from the stakeholders [H1, H3, A2, D2, D4, AG2]. Despite this, we see that support/collaboration is more than response/neutral behaviors within each stakeholder category.

\subsection{Formulation}

In the formulation stage, policy alternatives are developed in order to struggle with the existing problems in the agenda. Thus, the number of policy alternatives decreases and this facilitates the last decisions of policy makers (Kulaç and Özgür, 2017).

\subsubsection{Goals in the Field of Medical Tourism}

Stakeholders gave different answers to the first question of formulation stage which was "did you have a goal when you first began medical tourism?". Hospitals that started medical tourism with small teams in the beginning indicated that their primary goal was to prove themselves as a unit within their institutions [H1, H3]. They stated the ratio of medical tourism patients among the existing patients as follows:

[H1: $10 \%, \mathrm{H} 2: 35-40 \%, \mathrm{H} 3: 42 \%$ : "They saw us as a department which was investing abroad with no return....the point we have reached today.... We supported the evolution of health tourism concept. We have become solution partners of the countries abroad regarding health. We have become one of the leading groups and we aim to become one of the leading groups in the world."]

While academicians stated that their goal was to finish their theses or to publish scientific papers when they started medical tourism [A1], one academician declared that he was willing to guide country to use this potential [A3] and another one indicated no goal [A2].

Decision makers gave different answers to this question as there were some participants stating that actual situation was unknown due to the lack of healthy data [D1], that they had no goals [D2, D4] or that adopted the goal of making our country one of the most preferred destination in health tourism [D3]. Agencies indicated that they had a goal when they started this business [AG1, AG2] and one of them stated as;

"To become the biggest health tourism agency of Turkey" [AG3]

\subsubsection{Struggle with Competitors in Medical Tourism}

To the question as "How do you struggle with your competitors in medical tourism?", common keywords in the answers of private hospitals were found to be "quality service and price" [H1, H2, H3]. A healthcare facility indicating that they developed different marketing strategies for national and international competitors expressed itself as follows:

"..if you want to be a global player in health tourism, competitive war you have to fight should always be at quality level." [H3].

\subsubsection{The Desire of Public Hospitals to Carry out Medical Tourism}

It has been understood at the end of the interviews that presentation of health tourism service by the public institutions is not considered as a threat for private hospitals. As there is a hospital thinking that public and private hospitals provide service for distinct patient segments [H1], there are also healthcare institutions thinking that this situation may harm the image of the country if this process is not managed properly and required service quality is not provided [H2, H3]. A healthcare facility reported as;

:...if you start this business in public side by considering it only as a business opportunity without having a structure to embrace international patients properly and you can not achieve this service level, a negative feedback that will come from the foreign patients will also affect your private sector in the whole country.”[H3].

\subsubsection{Medical Tourism Promotion and Advertising Campaigns}

The question asking private hospitals about their promotion and advertising campaigns included in the context of medical tourism and the channels carrying out these activities was answered with the common keywords such as overseas offices, television, digital advertising-marketing and social media. A healthcare facility stated that the 
structure of the country affected their advertising and promotion campaigns by declaring as "communication tools are changing depending on the country and advertisement budgets are planned separately." [H1].

Academicians [A1, A3] and decision makers [D1, D4] mentioned that advertising and promotional activities were insufficient and unsuccessful. A decision maker answered relevant question as follows:

"With Official Gazzette dated as 08/03/2018 and numbered as 30498, International Health Services Inc. (USHAS) was established in order to promote services presented in our country in the field of international health, to support and coordinate activities of public and private sector for health tourism and to make suggestions to the relevant Ministry on policies and strategies for international health services and service presentation standards and accreditation criteria" [D3].

\subsection{Legitimization}

Legitimization is shown as a public policy analysis stage in which policy makers can evaluate different alternatives and public policies are fit in a frame and undertake the key role (Kraft and Furlong, 2004). During legitimization period, it is pointed out that not only the requests of policy makers but also the expectations of the individuals in the society should be met (Anderson, 2014).

\subsubsection{Standardization of Medical Tourism Services}

The services included in the scope of medical tourism should be legitimized for their implementation methods, mode of delivery, standards and control. In this context, hospitals seem to provide their services according to a certain standard and to set procedures [H1, H2, H3].

“...There are procedures and guidelines generated by us. The rules have been established spontaneously in time. We have a corporate culture." [H1]

“...yes, there is. We have admission procedures for foreign patients. As hospitals have admission procedures for VIP patients, we have these procedures for foreign patients. When patient arrives, we admit them according to these procedures." [H3]

It has been observed that decision makers, who have an important role at a level of policy making on this subject, have issued laws and regulations in order to carry out medical tourism activities in Turkey according to certain standards [D1, D3]. On the other hand, one of the decision makers stated that although it was intended to set standards, this was not easy as considered and a desired level of standards might not be established due to the cultural differences between the countries [D4].

"...we have a health tourism circular describing the process but there is no information on how patients come, how they will be met or on other parts. Each patient has a different expectation. This difference may vary across the countries. Therefore, it is difficult to create a specific standardization." [D4]

It was found that agencies that were mediating medical tourism activities conducted their services on medical tourism according to a certain standard. Although it varied according to the country from time to time, they were found to organize their activities on a single and holistic standard in general [AG1, AG2, AG3, AG4].

\subsection{Implementation}

Implementation process, that indicates the state of taking actions for the objectives set at the beginning of policy analysis process, is an integral part of Process Model. During the implementation stage of public policies emerged within a specific period, how created policies come to life is observed. This stahe is also important in terms of the solution of defined problem and reaching determined goals.

The questions that we asked to our stakeholders during implementation stage were not open-ended; and they were questions to be answered as yes/no in general. This was formed in this way due to the nature of implementation stage since policies created in a field either been implemented or not. Besides this, what our stakeholders offered as a reason for their answers will be indicated in the study.

\subsubsection{Self-Assessment of the Implementation Stage}

During the implementation stage of the policies established in the field of medical tourism, self-assessment of the stakeholders is one of the most curious topics of the researchers in this study. Evaluation of the current situation, 
that is the outcome of policy analysis process, with a realistic eye begins with the recognition of problems arising from implementation.

The question which we directed to the participants in order to measure their self-assessment abilities during the implementation stage of medical tourism policies was "Do you think that you are able to carry out implementation processes regarding medical tourism properly and completely?". The answers and justifications given to this question can be listed as follows;

Table 2. State of Carrying Out Implementation Processes of Medical Tourism Properly and Completely

\begin{tabular}{llllllllll}
\hline H1 & H2 & H3 & A1 & A2 & A3 & D1 & D2 & D3 & D4 \\
\hline Yes & Yes & Yes & Partially & Yes & No & No & No & Unanswered & No \\
\hline
\end{tabular}

It is seen that all hospital managers agree that they carry out implementation processes successfully. A participant that indicated how his opinion was formed in this direction made an explanation as follows;

“..we have a very solid procedure that many hospitals lack. We have nothing to call as deficiency. A very small error and a misunderstanding may be bad. For example; you have a phone call from someone saying that he is not taken on board... you do not have the chance not to care. If you don't, you will discard 30 individuals together with that patient. [H2]

It is seen that the same question was responded by different answers by the academicians. However, the question directed to the academicians was not in the context of self-assessment; and should be addressed as the evaluation of implementation performances of the healthcare institutions that they followed during their study.

An academician explained this situation with a familiar proverb: “..there is an understanding as make it up as you go along" [A3].

All our decision makers who answered relevant question indicated that there were missing things while managing the processes regarding the implementation of medical tourism policies. Following is the opinion of a decision maker regarding this issue:

"..we have a circular describing the process but there is no information on how patients come, how they they will be met or on other parts" [D1].

Undoubtedly, one of the striking results that can be drawn from the table above is that decision makers see deficiencies in implementation processes; and hospitals, that are the most significant actors among the implementers, see themselves as sufficient in implementation.

\subsubsection{Barriers in front of Medical Tourism Applications}

How accurate the rules, methods and policies that have been formed in a certain area only appears during the implementation stage of those policies. The first question that we asked to identify the barriers in front of medical tourism applications was whether our participants were influenced by international rules and malpractice in the area of health during implementation. The answers given to this question were as follows:

Table 3. State of being influenced by International Rules and Malpractice during Implementation

\begin{tabular}{|c|c|c|c|c|c|c|c|c|c|c|c|c|c|}
\hline H1 & H2 & H3 & A1 & A2 & A3 & D1 & D2 & D3 & D4 & AG1 & AG2 & AG3 & AG4 \\
\hline No & No & No & No & Yes & Yes & Yes & Yes & No reply & Yes & Yes & Yes & No & Yes \\
\hline
\end{tabular}

The answers given to our question was predominantly "yes"; and this shows that medical tourism parties see international rules and malpractice as a barrier limiting them. Unlike general perspective, hospital managers advocate that international rules and malpractice are not obstacles. An academician who agrees with the hospitals states as follows:

“...In order not to experience international problems, hospitals prefer to continue contacting with the patients even when they leave the hospital. I think what is promised to patients is realized in general.

Turkish Association of Private Hospitals (OHSAD) is now authorized to give visa to the international patients. The people who want to be treated here send their reports to the hospital if they experience visa problems; and visa 
is given by OHSAD. In other words, a person can come for a health service to a country where he/she can not come as a foreign tourist." [A1]

During the process in which we evaluated the barriers in front of the implementation of medical tourism policies, we directed a second question to the participants asking whether country rules and other unidentified unique situations blocked them or not.

Table 4. The Presence of National Barriers regarding Medical Tourism

\begin{tabular}{llllllllllllll}
\hline H1 & H2 & H3 & A1 & A2 & A3 & D1 & D2 & D3 & D4 & AG1 & AG2 & AG3 & AG4 \\
\hline No & Yes & Yes & No & No reply & Yes & Yes & Yes & No & Yes & Yes & Yes & Yes & Yes \\
\hline
\end{tabular}

Majority of the hospitals, which do not see international rules and malpractice as a barrier in front of medical tourism applications, agree that legal and different limitations in our country prevent them. Another hospital manager who responded the relevant question as 'yes' listed the barriers as follows:

“..visa problems are very serious. For instance, visa applications of Turkey against Africa prevent an income that may come from there seriously. I hope that a significant income will enter Turkey when these problems are overcome.

In addition, the problems arising in the working permits of foreign staff and sometimes difficulties arising in the extension of visas block health tourism." [H3]

Among "yes" answers, it was observed that decision making participants responded this question predominantly with "yes". One of our decision making participants justified his "yes" answer as follows:

"..there is a problem in data treasury of us. For that reason, we are unaware of who is doing what. We do not have a statistical bank that presents us what we are doing or there is nothing presented to us. Is the 2 billion dollar target presented to us far away? No, it is not; but we do not know what we are doing and also, we are not aware of this [D1].

\subsection{Evaluation}

During the evaluation stage, that is the last step of Process Analysis Model, it is aimed to detect to what extent the goals and objectives set have been achieved; and to correct and complete the aspects which were lacking and could not be achieved at a desired level( Tahtalıŏglu and Özgür, 2016; Kulaç, Çeliktürk, Tuğral and Çalhan, 2015).

\subsubsection{State of Success and Our Success Criteria in Medical Tourism}

First question of evaluation stage was "Do you think that you are successful in medical tourism service and what are your success criteria?" and it was aimed to enable actors to evaluate medical tourism outcomes/outputs. Common answers of healthcare facilities to the first question was "yes". Healthcare facilities commonly used the statements of "patient satisfaction and endorsement" as success criteria [H1, H2, H3].

Always being on the rise and persistence are two success criteria. In the context of this question, a hospital indicating that they got a positive response from the patients stated as follows:

"..success criteria as return, recommendation of us by our patients and their response as "yes" to the question asking if they come again are important."[H1].

While academicians agree that we are successful in the field of medical tourism, an academician stated as ;

“..successful but potential is not used efficiently." [A2] and another emphasized that success was not adequate by commenting as;

“..successful but partially.” [A3].

Two decision makers declared that we were successful in medical tourism service whereas they underlined endorsement [D1, D4], number of patients, quality, technology, ease of transportation and human resources [D1] as success criteria.

Agencies defined success in medical tourism as the number of patients coming and the benefits gained in return for the services you provide (money, appreciation, prestige, attracting more patients, etc.). Moreover, an agency 
officer indicated the state of "being recommended by the patients who received service from us to their environment when returned to their countries" [AG2] as success criteria.

The question as "How much of hospital's income is made up by the income derived from medical tourism?" was answered by two healthcare facilities as follows: [H2: 25-30\%, H3: 15-16\%]

\subsubsection{Reasons for Preference in Medical Tourism}

Reasons for preference in medical tourism were responded by a healthcare facility as;

“..accessibility, service quality, correct growth objectives, right promotion and image” [H3].

"Difference in price" occurs as the common word in the answers given by the academicians to the question as "why should our country be preferred by medical tourists?". In addition, an academician stated that each country had a different reason for preference and indicated a reason for preferring Turkey as its location at a four-hour flight to 1.5 billion people [A1]. While another academician featured the issue of reliability [A2], another one stated as follows;

“..quality health service, strategic location of the region and good quality of our doctors" [A3].

One of the decision makers summarized the reasons for preference as follows:

"The studies of Turkey to be most preferred leader country in the health tourism are continued effectively and efficiently by using its all advantages including its geographical structure, seasonal advantages, presentation of quality healthcare service, world class technological and medical equipment, affordable price advantage compared to Europe, thermal underground resources, young and dynamic population and traditional Turkish hospitality besides high quality and specialized human resources in medical staff within the healthcare facilities." [D3]

Although agencies gave different answers to this question, main theme was their understanding based on client satisfaction [AG1, AG2, AG3, AG4]. An agency tried to explain the situation as;

"Patients want to feel themselves safe when they go to a foreign country. We primarily embrace each patient from the moment he/she enters the country and we support them in all matters. We can offer them more than one hospital and doctor....they are accompanied by our health consultant who knows their native language during all processes." [AG3].

\subsubsection{Accreditation in Medical Tourism}

Healthcare facilities agreed on that accreditation is very important in medical tourism; and three healthcare facilities had a JCI Accreditation Certificate. One healthcare facility also had a certificate of excellence center in three branches.

All academicians share the opinion as accreditation is very important in medical tourism [A1, A2, A3]

A response from the decision makers was as follows;

"International Health Services Inc. (USHAS) was established to make suggestions to the Ministry on policies and strategies for international health services and service delivery standards and accreditation criteria." [D3]

\subsubsection{Qualification of the income From Medical Tourism}

While academicians thought that income derived from medical tourism was insufficient, they stated the things to be done as follows;

"..the increase in the collaboration of stakeholders is important." [A1],

“..more promotion, quality and reliable service." [A3].

One of the decision makers made a comment about the income derived from medical tourism as;

“..low, but potential is 20-25 billion dollars." [D1]. 
Süleyman Demirel Üniversitesi Vizyoner Dergisi, Yıl: 2021, Cilt: 12, Sayı: 30, 417-433.

Süleyman Demirel University Visionary Journal, Year: 2021, Volume: 12, No: 30, 417-433.

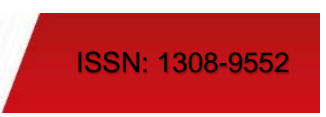

\subsubsection{Turkey's 2023 Goals for Medical Tourism}

All healthcare facilities responded to the questions such as "Can we achieve the goal of " 2 million individuals and 20 billion dollars"which is the goal of Turkey for medical tourism in 2023? What can be done for this?" as "yes" [H1, H2, H3]. Besides, hospitals made additions as;

"Actually we can reach more number of patients." [H1],

"Moreover, achieving this goal requires a multi-criteria study. At this point, Turkey should review itself and do its part." [H3].

Academicians responded the state of achieving 2023 medical tourism goals mostly as "yes" [A1, A2] . An academician indicated his view as follows;

“..no, we are too far but it is not impossible." [A3].

To the question asking what to do for this; an opinion was reported such as

“..promotion, advertisement and marketing network should be prioritized." [A2].

One of the decision makers responded this question as follows;

“..goal is not realistic." [D2].

Agencies mostly gave "yes " answer to the question asking the state of 2023 medical tourism goals of Turkey [AG1, AG3, AG4]. An agency commented as;

"No, it is impossible without an awareness on the industry." [AG2].

\section{DISCUSSION}

This study examines medical tourism policies from the perspectives of stakeholders which have an impact on the policies made in the field of medical tourism in Turkey at varying degrees.

It has been indicated that medical tourism market shows a growth at a rate of $20 \%$ each year (Turizm Aktuel, 2016). Considering this growth rate and 2023 strategic goals of Turkey, it can be stated that medical tourism phenomenon may be a very significant and potential source of income for Turkey. In this context, medical tourism was included in the context of 2013-2017 Strategic Plan which was prepared by the Ministry of Health in 2012 with the participation of public and private sector representatives, academicians and other stakeholders; and this study was carried out due to the fact that it has become an important public policy for Turkey and worth analyzing.

When the information taken from medical tourism stakeholders was examined, it was seen that medical tourism concept was set in the agenda in Turkey following 2000s primarily by decision makers, the hospitals then provided service in this subject and academicians carried out scientific studies regarding this topic at last. This finding shows similarities with the results of previous studies. The first study which was directly on medical tourism was conducted by Gümüş and Büyük (Gümüş and Büyük, 2008; İçöz, 2009).

It was found that medical tourism service was first provided by private sector in Turkey. As all stakeholders stated, this was confirmed by the condition that two hospitals that initiated medical tourism service were belong to private sector. The establishment of international patient departments for medical tourism especially within the private hospitals and support of associations and organizations on medical tourism are the results of that private hospitals see medical tourism as a business opportunity (Buzcu and Birdir, 2019). Two reasons of the involvement of medical tourism service on agenda in Turkey and provision of it as a service were reported by the participants as "business opportunity" and "incoming demand". According to a study performed in India, medical tourism was seen as a business opportunity (Arya, 2019). So that, the editor of MakeInBusiness, which is a website describing new trendy business opportunities, introduced medical tourism as a business opportunity in his article entitled "Starting a Medical Tourism Business-Growing Business Opportunity" written in 2019 (MakeInBuseiness, 2019).

One of the most striking results obtained from these studies is that most of the decision makers who make, implement and audit policies in the field of medical tourism see it as an "incoming demand from foreign patients" rather than a business opportunity. This situation can completely be explained by the perspectives of the parties. The description of it by the stakeholders in private sector as "a business opportunity" indicates that these 
stakeholders address the topic from a perspective of the motivational sources of medical tourists; on the other hand, perception of medical tourism as an "incoming demand from foreign patients" shows that these stakeholders address this subject in the context of the factors affecting the decision of tourists in dealing with medical tourism. Long waiting times, lack of desired medical treatment, high costs of medical care and negative attitudes towards healthcare system of the country are shown among the reasons pushing patients to be involved in medical tourism. Despite that, the reasons attracting patients to medical tourism are indicated as desire to get a quality and relatively cheaper healthcare service, an easy-to-access health service, opportunity to do classical tourism and getting a reliable health service (Çapar, 2019; Jotikasthira, 2010; Awadzi and Panda, 2005; Marlowe and Sullivan, 2007).

Formation of medical tourism policies as a result of services and applications in the scope of medical tourism in Turkey is explained by the lack of any regulations guiding stakeholders when service in this field was provided for the first time. In a study carried out with Buzcu and Birdir (Buzcu and Birdir, 2019) on 206 private hospital managers, disorganization and deficiencies in the health legislation for medical tourism were reported as problems by the hospital managers.

The most powerful weapon that hospitals providing medical tourism service in Turkey use to struggle with their competitors is described as quality service and low price strategy. In a study performed on this subject, Turkey was indicated as the country with the highest number of patients from abroad following India and Costa Rica; and the reason was associated with high quality and low-paid service (Peters and Sauer, 2011).

Based on the statements of private hospitals, successful implementation of difficult and complicated health services such as organ transplantation, bone marrow transplantation, oncology surgery and other complicated surgical operations in Turkey was linked to the use of high level health technology besides high quality of Turkish doctors and other healthcare professionals. In a study conducted by Kılınç (2017) it was found that service quality in medical tourism was good and adequate in Turkey; but, there were deficiencies such as insufficient communication of the staff, low capacity of mediating institutions and inadequate presentation of existing potential.

It has been seen that all stakeholders carry out advertising and promotional activities in the context of medical tourism; and these activities are mostly carried out through internet, digital marketing and overseas office channels. According to a SWOT analysis study performed by Aydın and Aydın (2015) on marketing applications for medical tourism, it was indicated that most of the marketing activities was carried out through the Health Tourism Guide which was established digitally on internet.

It was also determined that it was quite impossible to make a standardization based on hospitals in the presentation of medical tourism due to the cultural differences between the countries; but, there were standards on how and by whom these services would be provided within the framework of general medical tourism policy. It was reported that health tourism guide published in Turkey provided a certain standardization on this subject (Turkey Medical Tourism Guide, 2019). Undoubtedly, it is a striking result that decision makers declared some deficiencies in the applications of medical tourism unlike hospital representatives. In the light of a previous study, it was indicated that these were generally associated with communication and coordination in Turkey (Aydın, Aypek, Aktepe, Şahbaz and Arslan, 2019).

Stakeholders except hospitals stated that they saw international rules and malpractice as a barrier for themselves. Despite this fact, it is challenging that participated hospitals see the legal and different limitations in Turkey (visa, advertising and promotion, opening a medical unit, etc.) as barriers to themselves. According to a study, barriers in front of health tourism were indicated as language problems across the countries, differences in healthcare systems and cultural differences (Lengyel and Otvos, 2003). As in good examples like Thailand, Turkey also needs to overcome all bureaucratic obstacles in medical tourism. It was also stated that Turkey might be included in the world destination ranking by making a major breakthrough (Çakır, 2017).

It has been denoted that medical tourism activities in Turkey are successful from the perspectives of stakeholder hospitals and decision makers and partially successful from the perspective of academicians. While success criteria were endorsement and patient satisfaction according to the hospitals and positive feedbacks according to the agencies, the number of patients and endorsement are seen as the most important success criteria according to the decision makers. It was also reported that international patients had a wide range of selection criteria, but the most important ones were innovative applications, success stories and modern medical technology (Can, Bayraktaroğlu and Atalıç, 2014). It should be noted that factors affecting success criteria including the number of patients, 
endorsement, etc. are shaped by the preferences of the patients. In this context, we can suggest that Turkey will achieve success with its strengths.

Criteria such as accessibility, service quality, correct promotion and image, affordable price, having a location at a four-hour flight distance, reliability, having a world class technological and medical equipment and having tourism opportunities are shown among the reasons for preferring Turkey as a medical tourism destination. It can be pointed out that outputs obtained in this context are similar to the results of many studies (Çapar, 2018; Khafizova, 2011; Jotikasthira, 2010; Can, Bayraktaroğlu and Atalıç, 2014; Çapar, 2019).

\section{CONCLUSION}

The phenomenon of medical tourism which began to be spoken in the world since 1990s was set in the agenda of Turkey in 2000s; and foreign patients were begun to be provided service by the actors following 2010 as a great business opportunity. Medical tourism service was first given by the hospitals in private sector; and it is possible to state that a new stakeholder emerged in the relevant sector by the creation of supply by the public hospitals. This situation is welcomed by the private hospital participants and thought to contribute to the development of medical tourism. Although lack of a legislation that would guide medical tourism stakeholders at the time of commencement of services was indicated as a problem for the actors in the sector, basic standards and procedures have been established over time. In this context, it is among the issues where many of our participants agree that the policies in the field of medical tourism are formed after medical tourism applications. Considering the environment of medical tourism, all participants described common stakeholders: Ministry of Health, Ministry of Culture and Tourism, Hospitals, Universities, SATURK, USHAS, OHSAD, TURSAB and agencies. In the studies for increasing the market share of Turkey in medical tourism globally, participation and collaboration of all stakeholders seem quite important. In Turkey, medical tourism service is given in all branches; and complicated surgeries, organ transplantations and oncological treatments have become the featured services. Turkey has a big advantage for human resource and medical technologies in the implementation stage of the policies. Private sector, which considers the number of patients, patient satisfaction and endorsement as the success criteria, indicated that it achieved the goals set in the beginning during the evaluation stage of medical tourism. Participants also noted that Turkey was quite far away from achieving 2023 target which was ' 2 million individuals and 20 billion dollars'. The inadequacy of promotional campaigns has been shown as a reason for this. It was also seen that many participants, who did not see international rules and malpractice as a barrier in front of medical tourism, stated that they met some obstacles in Turkey. The most typical one among these obstacles was pointed out as visa problems of the foreign patients and legal legislation limitations.

In this study evaluating public policies in medical tourism in five stages based on Process Analysis Model, one of the most significant outcomes is the fact that our medical tourism potential is not used sufficiently as agreed by all participants.

The continuity of research in this framework and its deepening in the field of medical tourism marketing will contribute to the literature as well as the success of Turkey in medical tourism.

All participants stated that medical tourism should become a country policy. In the light of this result, this study is thought to be a roadmap for all countries working on medical tourism to form a policy. Most studies on medical tourism so far have been conducted based on the views of only one or two stakeholders. However, with this study, it has been carried out by including the views of all stakeholders in making medical tourism policy in any country. This shows that the results of this study can be beneficial to most stakeholders operating in the medical tourism industry.

\section{DECLARATION OF THE AUTHORS}

Declaration of Contribution Rate: The authors have equal contributions

Declaration of Support and Thanksgiving: No support is taken from any institution or organisation.

Declaration of Conflict: There is no potential conflict of interest in the study. 


\section{REFERENCES}

Anderson. J. E. (2014). Public policymaking: An introduction. 8th edition, Stamford Connecticut: Cengage Learning.

Arya, N. (2019), Medical tourism brings tons of business opportunities in healthcare sector. Access adress: https://www.franchiseindia.com/wellness/medical-tourism-brings-tons-of-business-opportunities-inhealthcare-sector.12585, (21.12.2019).

Aydin, D., Aypek, N., Aktepe, C., Sahbaz, P. and Arslan, S. (2019), The future of medical tourism in Turkey. Access adress: https://www.byclb.com/Files/turizm/turkiyede-medikal-turizm-gelecegi.pdf, (22.12.2019).

Aydin, G. and Aydin, B. K. (2015). Comparative situation analysis and marketing applications in healthcare tourism around the globe and in Turkey, Journal of Marketing and Marketing Research, 16, 1-21.

Ayranci, P., Ayaz, F., Yasar, N. and Yuksel, E. (2018). Presentation of health tourism content in newspapers, ECIDER-Electronic Republican Communication Journal, 1(1), 64-80.

Awadzi, W. and Panda, D. (2005). Medical tourism: Globalization and marketing of medical services, The Consortium Journal of Hospitality and Tourism, 11(1), 75-80.

Buzcu, Z. and Birdir, K. (2019). Review of medical tourism in Turkey: A study of private hospitals, Gaziantep University Journal of Social Sciences, 18(1), 311-327.

Can, A., Bayraktaroğlu, H. and Atalıç, H. (2014). Global perspective medical tourism management in Turkey, Mehmet Akif Ersoy University Journal of Social Sciences Institute, 6(11), 73-81.

Çakır, R. (2017). What is the biggest obstacle to health tourism?. Access adress: https://www.turizmaktuel.com/haber/saglik-turizminin-onundeki-en-buyuk-engel-ne, (22.12.2019).

Çapar, H. (2018). Factors influencing medical tourism destination choice: A study aimed at measuring Turkey's perception of foreign medical tourists. Master's Thesis, . İstanbul University Institute of Health Science, İstanbul.

Çapar, H. (2019). Sources of motivation affecting the decision of potential Medical tourists, Journal of Management, Economics and Marketing Research, 3(6), 252-264.

Dye, T. R. (2016). Understanding public policy. (15th Edition), Pearson Publisher.

Gumus, F. and Buyuk, O. (2008). New expansions in health tourism: medical tourism. III. Balıkesir National Tourism Congress, 17-19 April 2008, Balıkesir, 433-442.

İçöz, O. (2009). Scope of health tourism medical tourism, Facilities of Turkey, Journal of Yasar University, 4(14).

Jann, W. and Wegrich, K. (2007). Theories of the policy cycle. F. Fischer, G. J. Miller and M. S. Sidney (Ed.), Handbook of Public Policy Analysis in (43-61). Boca Raton, FL: CRC Press, Taylor \& Francis Group.

Johnston, R., Crooks, VA., Snyder, J. and Kingsbury, P. (2010). What is known about the effects of medical tourism in destination and departure countries? A scoping review. International Journal for Equity in Health, 9(1), 24.

Jotikasthira, N. (2010). Salient factors influencing medical tourism destination choice. Doctoral Thesis, Southern Cross University.

Kaptı, A. (2004). Kamu politika sürecinde klasik yaklaşım modeli. A. Kaptı (Ed.) Kamu politika süreci, Kraft EM, and Furlong SR. Public Policy: Politics, CQ Press, Washington D.C: Analysis and Alternatives.

Khafizova, L. (2011). Importance of travel agencies in medical tourism development and situation in Turkey. Master Thesis, Istanbul University, Istanbul.

Kılınç, I. (2017). A field study on service quality and customer satisfaction in medical tourism industry in Turkey. Suleyman Demirel University Visionary Journal, 8(17), 130-143. doi:10.21076/vizyoner.281861. 
Kulaç, O., Çeliktürk, T., Tuğral, M. and Çalhan, H. S. (2015). Assessing the significance of planning approaches in public administration: Case of Turkish Ministry of Culture and Tourism Strategic Plan (2010-2014). 3rd Mediterranean Interdisciplinary Forum on Social Sciences and Humanities, MIFS, 17-19 May, Barcelona, Spain.

Kulaç, O. and Ozgur, H. (2017). An overview of the stages (heuristics) model as a public policy analysis framework. Eur Sci J, 13(12), 144-57.

Lengyel, G. and Otvos, P. (2003). Cross-border cooperation in health care in the acceding countries. Free movement and cross-border cooperation in Europe, Luxembourg: Entente Des Hospitaux Luxembourgeois: The Role of Hospitals \& Practical Experiences in Hospitals.

Lunt, N., Smith, R., Exworthy, M., Green, S. T., Horsfall, D. and Mannion. R. (2011). Medical tourism: treatments, markets and health system implications: A scoping review, Paris: Organisation for Economic Cooperation and Development.

MakeInBusiness. (2019). Starting a medikal tourism business-growing business opportunity, Access adress: https://makeinbusiness.com/starting-a-medical-tourism-business/, (21.12.2019).

Marlowe, J. and Sullivan, P. (2007). Medical tourism: the ultimate outsourcing. HR Human Resource Plannin, $30(2), 8-10$

Peters, C. R., Sauer, K. M. (2011). A survey of medical tourism service providers. Journal of Marketing Development and Competitiveness, 5(3),117-126.

Ruggeri, K., Ivanović, N., Razum, J., Kácha, O., Menezes, I. G., Zafari, Z., Garcia-Garzon, E. (2018). An evidencebased policy for improving choice in global health access through medical travel. Health Policy, 22(12), 1372-1376.

Sabatier, P. A. (1991). Toward better theories of the policy proces. PS: Political Science and Politics, 24(2), doi:10.2307/419923.

Smith, R., Álvarez, M. M. ve Chanda, R. (2011). Medical tourism: A review of the literature and analysis of a role for bi-lateral trade. Health Policy, 103(2-3), 276-282.

Kaptı, A. (2011). Teorik perspektifler. Ankara: Seçkin Yayıncılık.

Turizm Aktuel. (2016). That Turkey's 2015 health tourism income. Access adress: http://www.turizmaktuel.com/haber/iste-turkiye-nin-2015-saglik-turizmi-geliri, (20.12.2019).

Turkey medical tourism guide. (2019). Access adress: http://turkeyhealthtourismguide.com/, (22.12.2019).

Tahtalioglu, H. ve Ozgur, H. (2016). Analysis of the development agencies policy in turkey: Process analysis Step Approach). Niğde University Faculty of Economics and Administrative Sciences Journal, 9(3), 161-184.

Yildirim, A. ve Simsek, H. (2018). Qualitative research methods in social sciences. 11th Edition, Ankara: Seçkin Publishing.

Walt, G. ve Gilson, L. (1994). Reforming the health sector in developing countries: The central role of policy analysis, Health Policy and Planning, 9(4), 353-370. doi:10.1093/heapol/9.4.353 